\title{
Privatization threat recedes for British labs
}

London. Two of Britain's largest research councils learned with relief this week that the government is not being advised by a team of 'efficiency' experts to require a major upheaval in their relationships with their research institutes.

In particular, neither the National Environment Research Council (NERC), nor the newly-formed Biotechnology and Biological Sciences Research Council (BBSRC), will be required either to sell off any institutes to the private sector, or even to deal with them at excessively arm's length.

At the same time, the Scottish Office has successfully argued that the government give close attention to it being allowed to take over responsibility for a wide range of government-sponsored research institutes based in Scotland.

Both conclusions have emerged from the eagerly awaited report of a team of civil servants set up at the end of last year under the government's 'efficiency adviser', Sir Peter Levene, to suggest ways of rationalizing 53 government research institutes.

Early fears had been raised that the group was intended to prepare the ground for rapid privatization. Indeed, one of its terms of reference was "to identify those public sector research establishments where early privatization is feasible and desirable".

But its report, on whose conclusions the government is inviting public comment partly in response to pressure from the scientific community, recommends that only one organization should fully take such a step, namely the Agricultural Development Advisory Service (ADAS) of the Ministry of Agriculture, Fisheries and Food (MAFF).

\section{AIDS policy chief quits after criticism}

Washington. President Bill Clinton's AIDS policy chief, Kristine Gebbie, has resigned after only 11 months in the job, and after mounting criticism of her performance.

Almost from the time of her appointment, AIDS experts said that the former Washington State health-care official lacked the political skills needed to fill the ill-defined 'AIDS czar' role that Clinton had promised to create during his election campaign.

No successor to Gebbie has been nominated. But names being circulated include that of Tim Westmoreland, a staff member on the House of Representatives health and environment subcommittee chaired by Henry Waxman (Democrat, California). AIDS activists and researchers are hoping that the White House will put some thought into redefining the job before it is filled.
Similarly the report expresses little enthusiasm for an alternative idea, mooted by Levene himself in a separate report published last year, that all the institutions covered be linked into a single Civil Research Agency, comparable to the Defence Research Agency already set up to run the government defence research establishments.

In the end, the team has put forward two alternative solutions. One would be to link together government research institutes into four separate groupings each oriented towards a specific 'market sector'. These would cover the fields of marine resources and the environment; the non-marine environment; biotechnology and biological science; and food and agriculture.

Under such a solution-recommended in an pre-

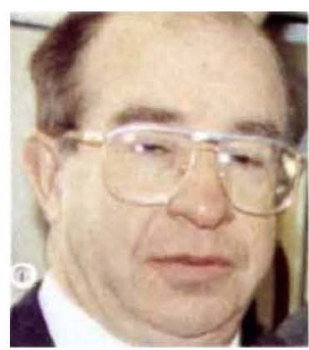

Levene: cutbacks not ruled out. liminary version of the team's conclusions (see Nature 369,5 ; 1994) - the four groupings would become the responsibility of the Scottish Office, the NERC, and BBSRC and the MAFF respectively.

Each grouping would have its own chief executive. But whereas the initial proposal requires four new appointments - a move which some feared could introduce a potential conflict within the two groupings run by research councils - the new proposal is that in these two cases, the role of CEO would be taken on by the CEO of the research council itself.

The alternative proposal put forward by the scrutiny team to create geographicallybased groupings, in practice meaning a single grouping for Scotland, run by the Scottish Office, and three in England and Wales, run by the BBSRC, NERC and MAFF.

This proposal did not feature in the team's preliminary conclusions. Nor is it a solution favoured by the two research councils, which would each lose control of their institutes north of the border.

But it is one that has considerable political backing from the Scottish Office itself, keen to promote what it describes as the 'Scottish model' for organizing research involving both the vertical and horizontal integration of research teams and institutes.

In addition to these two structural changes, the scrutiny team makes a number of general recommendations about how the effectiveness of government-funded laboratories could be increased. For example, it recommends that both government departments and the research councils "routinely examine" the potential for transferring the research institutes for which they are cur- rently responsible to universities.

It also makes a number of specific recommendations for the future of institutions where it claims to have discovered overlapping responsibilities. For example, it suggests that part of the Medical Research Council's (MRC's) Radiobiology Laboratory and the National Radiological Protection Board should be brought together.

Although the team has declined to put any figures on either the costs of such mergers or on the number of jobs that might be lost - and Levene claims that rationalization does not necessarily mean cuts - he admits that "there might be cuts; it depends on what happens during the final decisionmaking process".

Similarly, some of the individual proposals for mergers are likely to meet with resistance. One is that responsibility for the Roslin Institute in Midlothian, an important centre for animal genetics, be transferred from the BBSRC to the Scottish Office.

In general, however, the scrutiny team's proposals have been given a cautious welcome by many of those who will be most directly affected, and had previously been concerned that the government might be tempted to take more radical measures.

Tom Blundell, for example, chief executive of the BBSRC, says that the report represents an "endorsement" of the efforts the research council has itself been making to rationalize its activities in recent years.

Blundell also claims that the team's report acknowledges that the need for a strategic overview on research means that the 'customer-contractor' relationship introduced by Lord Rothschild in the early 1970 s cannot be applied "in an undiluted form" to the relationship between research councils and their institutes.

The strongest reaction has come from the Institute of Professional, Managers and Specialists, the trade union which represents 31,000 scientists working in government laboratories covered by the report.

Valerie Ellis, the union's assistant general secretary, warns that privatization remains enshrined "as a long-term aim for all establishments". But she also acknowledges that scientists will be relieved that their worst fears of a mass privatization programme have not been realized.

William Waldegrave, the minister for science, has said that the government will only decide on what action to take after a four-month consultation period, due to end in November. And in case neither of its two main proposals are acceptable, the scrutiny team has also recommended a third 'fallback' solution - the appointment of two 'directors of rationalization' charged with carrying out the government's aims through less confrontational (and no doubt less expensive) techniques.

David Dickson 